doi: $10.35757 /$ KiS.2019.63.3.11

\begin{tabular}{llr} 
KULTURA & $\begin{array}{l}\text { POLSKA A KADEMIA NAUK } \\
\text { KOMITET SOCJOLOGII }\end{array}$ & ISSN 0023-5172 \\
i & INSTYT T STUDIÓW POLITYCZNYCH & \\
SPOLECZENSTWO & 2019, nr 3 W SETNĄ ROCZNICĘ URODZIN ANTONINY KŁOSKOWSKIEJ \\
\hline
\end{tabular}
$\begin{array}{llllllll}A & R & T & Y & K & U & Ł & Y\end{array}$
I
$\begin{array}{llllllll}\mathrm{R} & \mathrm{O} & \mathrm{Z} & \mathrm{P} & \mathrm{R} & \mathrm{A} & \mathrm{W} & \mathrm{Y}\end{array}$

RAFAŁ SMOCZYŃSKI

Instytut Filozofii i Socjologii PAN

\title{
KONTROWERSJE DOTYCZĄCE URAŻANIA UCZUĆ RELIGIJNYCH: ANALIZA WYBRANYCH ASPEKTÓW DEBATY PUBLICZNEJ*
}

\section{WSTĘP}

Historyczna analiza przypadków kontrowersji dotyczących zarówno urażania uczuć religijnych, jak i bluźnierstw wykazuje znaczną zmienność oceny tych aktów (Levy 1993). Spotykały się one ze zróżnicowaną reakcją w zależności od momentu historycznego i kontekstu społeczno-politycznego, w których się ujawniały, co sugeruje, że znaczenie ich szkodliwości było konstruowane społecznie, a następnie określoną decyzją prawną czy polityczną naturalizowane w obrębie obowiązującego kontekstu „władzy-wiedzy” jako „obiektywne”, „bezstronne” itp. W czasach przednowoczesnych bluźnierstwo w świecie Zachodu rozumiano jako akt obrażający Boga albo obiekty sakralne, a poszkodowaną osobą było bóstwo, którego gniew wynikający z okazanego mu braku respektu mógł dotknąć ludzi (np. przez sprowadzenie plag czy trzęsienia ziemi) (Baumgartner 2013). Władze świeckie i duchowne zwalczały akty bluźniercze gorliwie i stanowczo, wprost proporcjonalnie do znaczenia funkcji ideologii religijnej

Adres do korespondencji: rsmoczyn@ifispan.waw.pl; ORCID: 0000-0003-3094-9148

* Niektóre argumenty tego artykułu zostały przeze mnie wcześniej przedstawione jako niepublikowana opinia biegłego w procesie sądowym (sygn. akt VIII K 517/13, SR Warszawa Mokotów, 2017). 
w procesie legitymizacji średniowiecznych stosunków władzy. Wszelako historyczna analiza ewolucji postrzegania szkodliwości bluźnierstwa wskazuje, że w definicji tych aktów, zwłaszcza wyartykułowanych w dyskursie prawniczym, punkt ciężkości stopniowo przesuwał się $z$ ochrony osoby bóstwa i obiektu sakralnego w stronę ochrony dobra społecznego i jednostek. Także sposób wymierzania kar bluźniercom w miarę zbliżania się do nowoczesności tracił surowość czasów Średniowiecza, co zazwyczaj literatura wiąże ze zmniejszaniem się roli religii w przestrzeni społecznej (Foucault 1998; Hunt 1999).

Jednak mimo procesów świecczenia narodów Zachodu, zapoczątkowanych głównie w Oświeceniu, jeszcze w XIX i XX wieku w wielu państwach europejskich religia była postrzegana (przynajmniej deklaratywnie) jako istotny element wzmacniający spoistość społeczną i ład moralny. Dopiero począwszy od XIX wieku akty wcześniej definiowane jako bluźniercze zredefiniowano jako akty wymierzone $\mathrm{w}$ ład publiczny albo naruszające uczucia religijne jednostek i jako takie mogły stać się przedmiotem postępowania procesowego. Także współcześnie w szeroko rozumianym świecie Zachodu prawa jednostek do wyrażania kontrowersyjnych sądów o religii albo produkowania kontrowersyjnych ilustracji/filmów dotyczących kwestii religijnych mogą być zawieszone w celu uniknięcia niepokojów społecznych. Wystarczy tu przywołać dwie, relatywnie niedawne decyzje sądów, które zakazały dystrybucji filmów ocenionych jako zawierające treści obraźliwe dla wrażliwości religijnych chrześcijan w Austrii w 1994 roku (sprawa Otto-Preminger Institute) i w Wielkiej Brytanii w 1997 roku (sprawa Wingrove) ${ }^{1}$. W obu przypadkach zakaz wyświetlań i dystrybucji filmu wyprowadzono ostatecznie $z$ ustaleń Europejskiej konwencji praw człowieka (EKPC), z artykułu 10 paragrafu 2, który zezwala na ograniczenie wolności ekspresji, jeśli ta miałaby stanowić zagrożenie dla bezpieczeństwa publicznego.

Ustalenie modus vivendi regulującego interakcje między wolnością słowa a ochroną uczuć religijnych jest zazwyczaj arbitralne. Jedno z kryteriów,

${ }^{1}$ Otto-Preminger-Institut für audiovisuelle Mediengestaltung (OTI) w 1985 roku ogłosił plan rozpoczęcia wyświetlania serii filmów (Das Liebeskonzil) karykaturyzujących niektóre założenia doktrynalne chrześcijaństwa. W wyniku protestów Kościoła katolickiego prokuratura austriacka wszczęła postępowanie w sprawie znieważnia uczuć religijnych przez OTI. W rezultacie materiały audiowizulane OTI zostały zajęte przez sąd i nie doszło do projekcji filmów. W 1989 roku British Board of Film Classification odmówił filmowi Visions of Ecstasy w reżyserii Nigela Wingrove'a przyznania certyfikatu dopuszczającego do dystrybucji, stwierdzając, że naruszaon prawo o zakazie szerzenia bluźnierstwa. Ta decyzja uruchomiła długi proces postępowania sądowego zakończony rozstrzygnięciem niekorzystnym dla reżysera. 
po które sądy sięgały w takich rozstrzygnięciach, zwłaszcza w świecie anglosaskim, często przywoływane w literaturze specjalistycznej, nawiązuje do werdyktu sędziego lorda Coleridge'a z 1883 roku wprowadzającego konieczność rozróżnienia między treścią a sposobem ekspresji danej treści: dopóki nawet najbardziej krytyczne opinie o religii nie są wypowiadane w formie obraźliwej, dopóty są dopuszczalne (Jones 1980) ${ }^{2}$. Na przykład w ocenie Petera Jonesa (1980) to rozróżnienie ułatwiało sądom rozstrzygnięcie, co jest uprawnioną drogą wyrażenia swojego stanowiska, a co jest próbą obrażenia określonej grupy ludzi. Dlatego nawet jeśli można zidentyfikować określoną nadwyżkę „przemocy symbolicznej”, na przykład w karykaturalnym przedstawieniu symbolu religijnego, co może być oceniane jako nieproporcjonalne do wartości artystycznej karykatury, nie jest to tożsame ze stwierdzeniem, że ta ekspresja naruszyła uczucia religijne w rozumieniu naruszenia bezpieczeństwa publicznego, tak jak to ujmuje na przykład EKPC 10(2), albo że był to przejaw zamysłu bezpośredniego urażenia uczuć religijnych, a tym samym był czynem zabronionym na przykład w ustawodawstwie polskim. Adekwatne wydają się tutaj także uwagi Jonesa (1980), który sugeruje, że religie wpływają na współkonstytuowanie postaw politycznych, kulturowych i społecznych wykraczających poza nisze wyznawców, a tym samym stają się doświadczeniem innych osób, które nie są członkami danej wspólnoty religijnej. Osoby religijne nie mogą zatem domagać się absolutnej opieki prawnej przed krytyką, którą ocenią jako obraźliwą. Aby została podjęta interwencja prawna, musi zachodzić uzasadniona obawa, iż dane treści czy ilustracje stwarzają poważne zagrożenia dla porządku publicznego. Albowiem nawet jeśli współczesne państwa demokratyczne sięgają po EKPC 10(2) czy po prawo narodowe regulujące kwestie ochrony uczuć religijnych, to dzieje się to w sytuacjach wyjątkowych, a nie rutynowo.

Sądy, zachowując ostrożność w ocenie domniemanej krzywdy wyrządzonej osobom religijnym, starają się nie tylko odróżnić podniesienie faktu obrażenia uczuć religijnych od ukrytej próby cenzorskiej, ale także uwzględnić kontekst społeczny czy intensywność domniemanego aktu obrazy. Istotnym elementem $\mathrm{w}$ tym wypadku jest ocena, $\mathrm{w}$ jakim stopniu reakcja społeczna jest proporcjonalna do istoty domniemanego aktu

2 Istota decyzji sędziego Johna Coleridge'a w sprawie redaktora „The Freethinker” G.W. Foote sprowadza się do tego, że treść danego stanowiska albo aktu nie może być definiowana jako bluźnierstwo, jeżeli jest wyrażona w umiarkowany i wyważony sposób, gdyż wówczas nawet atak na fundamenty wiary nie może stać się przedmiotem postępowania kryminalnego (Jones 1980). 
godzącego w uczucia religijne, protesty bowiem mogą być wyrazem paniki moralnej ${ }^{3}$, która jest spowodowana nie tyle krzywdą wywołaną obrazą uczuć religijnych, ile raczej stanowi przykład mobilizacji politycznej jednostek i instytucji dążących do cenzurowania określonej artykulacji, a tym samym jest próbą ograniczenia wolności słowa. Tak właśnie było $\mathrm{w}$ ocenie niektórych komentatorów $\mathrm{w}$ przypadku reakcji grup chrześcijańskich wobec faktu rozpowszechniania zdjęć instalacji „PissChrist” Andreasa Serrano czy wzburzenia szerokich sektorów społeczności muzułmańskiej wywołanego publikacją satyrycznej ilustracji Kurta Westergaarda przedstawiającej proroka Mahometa $\mathrm{z}$ bombą $\mathrm{w}$ turbanie zamieszczonej w duńskim czasopiśmie w 2005 roku (ponownie w 2008 roku) (zob. np. Carens 2006; Fuchs, Kamiński 2009). W wyniku tej ostatniej kontrowersji zamieszki wybuchły w kilkunastu krajach świata, niektóre z nich doprowadziły do śmiertelnych ofiar. Pamiętać trzeba o tym, że nawet jeśli niektóre $z$ kontrowersyjnych ilustracji pojawiły się początkowo $w$ kanałach komunikacji, z których zapewne nie korzystały wówczas osoby gorliwe religijne, to współczesna struktura mediów zachwiewa hierarchizację tożsamościową rynku medialnego/scenicznego. Zdekonstektualizowane fragmenty uwalniają się od swoich pierwotnych ram i uzyskują "drugie życie medialne”, a tym samym docierają do środowisk, do których kiedyś nie dotarłyby.

Kontrowersje związane $z$ aktami uznawanymi przez część opinii publicznej za godzące $\mathrm{w}$ uczucia religijne nie ominęły także Polski. W tym kontekście wymieniane są zazwyczaj fakty opublikowania w polskiej prasie następujących ilustracji: Matki Boskiej Częstochowskiej z posłem Markiem Jurkiem (tygodnik „Poznaniak” z 1993 r.), Matki Boskiej Częstochowskiej i Jezusa Chrystusa w maskach przeciwgazowych (tygodnik „Wprost”, 1994), zdeformowanego karykaturalnie tradycyjnego wizerunku Najświętszego Serca Pana Jezusa (tygodnik „Nie”, 2015). Kontrowersje dotyczyły także wydarzeń artystycznych (m.in. instalacji Pasja Doroty Nieznalskiej [2001/2002], wzburzenie części katolickiej opinii publicznej wówczas wywołało zestawienie krzyża-obiektu czci religijnej z penisem).

${ }^{3}$ Socjologia paniki moralnej, wyrastająca $z$ tradycji teorii konfliktu społecznego i teorii etykietowania, bada reakcje czynników kontroli społecznej wobec nowego i potencjalnie niepokojącego fenomenu, który stwarza — bądź o którym twierdzi się, że stwarza — zagrożenie dla pewnych „pozycji, statusów, interesów, ideologii i wartości” (Goode, Ben-Yehuda 1994, s. 11-12; por. Cohen 1972, s. 191). Po uważnym zbadaniu okazuje się, że zjawiska, które wywołują silne reakcje paniczne, nie stanowią istotnego zagrożenia, jak wynikałoby to $z$ obrazu przedstawionego w mediach czy w opiniach „ekspertów moralnych”. Wyolbrzymiona skala rzekomego zagrożenia stanowi zatem podstawowy wskaźnik paniki moralnej (Goode, Ben-Yehuda 1994, s. 36-38), 
Inne przykłady dotyczą ogólnopolskich protestów wobec planów wystawienia sztuki Golgota Picnic na Malcie Poznańskiej w 2015 roku, spektaklu Klatwa w Teatrze Współczesnym z 2017 roku) czy deathmetalowego koncertu muzycznego (podczas którego Adam Darski z zespołu Behemoth w 2007 roku porwał publicznie Biblię). W większości wymienionych przypadków polskie organy sprawiedliwości albo umarzały postępowania albo sprawców tych czynów uniewinniono, w niektórych wymienionych przypadkach dalej toczą się postępowania sądowe.

Oczywiście nie należy zapominać, że współczesne społeczności religijne (zarówno chrześcijańskie, jak i muzułmańskie czy żydowskie, a także inne grupy religijne, tutaj nie analizowane) są wewnętrznie zróżnicowane, także ze względu na reakcje wobec kontrowersji związanych $z$ urażaniem uczuć religijnych. Na przykład polskiego katolicyzmu nie należy postrzegać jako formacji, której członkowie mają jednolite przekonania polityczne, preferencje kulturowe, a nawet opinie w sprawach doktrynalnej i moralnej nauki Kościoła. Istnieją badania pokazujące znaczące zróżnicowanie tej społeczności w zakresie tak fundamentalnych kwestii jak opinie na temat ochrony życia poczętego, etyki seksualnej czy posłuszeństwa autorytetowi biskupów (np. zob. Hall 2012). Nie można a priori wykluczyć podobnie zróżnicowanego podejścia omawianej grupy do oceny szkodliwości wybranych kontrowersji godzących w uczucia religijne. Zatem jeśli określone publikacje, instalacje artystyczne czy filmy budzą konsternację, a nawet oburzenie części polskich katolików, nie zawsze oznacza to, że jest to dla nich taki rodzaj zniewagi, który wymaga zainicjowania postępowania karnego.

Jest jeszcze jeden poziom zróżnicowania środowisk religijnych, który wymaga tu komentarza. Gwałtowne reakcje środowisk fundamentalistycznych czy konserwatywnych często przesłaniają głosy sprzeciwu wobec aktów godzących w uczucia religijne artykułowane przez przedstawicieli religii publicznych, którzy kwestionują autonomię świeckich sfer państwa (ekonomii, polityki, kultury) przez wzniecanie debat na temat relacji między prywatną a publiczną moralnością i roli organizacji religijnych w kształtowaniu infrastruktury normatywnej i instytucjonalnej współczesnych społeczeństw (zob. Casanova 2005). Przedstawiciele religii publicznych bez uciekania się do gwałtownych form protestu mogą także krytykować wybrane akty godzące w uczucia religijne, co jest elementem ich zaangażowania w sferę publiczną i braku zgodny na marginalizacje i prywatyzację religii. Wreszcie obok wystąpień przedstawicieli religii większościowych należy dostrzec także przypadki sprzeciwu wobec wybranych aktów ocenianych jako obraźliwe artykułowane przez mniej- 
szościowe wspólnoty religijne, na przykład scjentologów czy członków Towarzystwa Świadomości Kryszny ${ }^{4}$.

\section{ZMNIEJSZANIE SIĘ ROLI RELIGII W STRATEGIACH LEGITYMIZACJI I PRODUKCJI WIEDZY}

Co interesujące, mimo znacznych emocji towarzyszących omawianym kontrowersjom toczona w polskich naukach społecznych i humanistycznych dyskusja poświęcona problemowi urażaniu uczuć religijnych jest znikoma (choć bywa podnoszona; zob. np. Tokarska-Bakir, Zawadzka 2015). Poza pracami o charakterze teologicznym (np. Gryz 2013) w literaturze akademickiej dominują ekspertyzy prawnicze, zazwyczaj uszczegółowiające doktrynę wyznaczoną artykułem 196 kodeksu karnego, który stanowi: „kto obraża uczucia religijne innych osób, znieważając publicznie przedmiot czci religijnej lub miejsce przeznaczone do publicznego wykonywania obrzędów religijnych podlega grzywnie, karze ograniczenia wolności albo pozbawienia wolności do lat dwóch" (zob. Kłaczyńska 2014; Dziwisz 2017; Żukowska 2016). Jak pokazała między innymi Małgorzata Tomkiewicz (2012), doktryna rodzi szereg sporów interpretacyjnych, począwszy od kwestii dotyczącej przedmiotu ochrony (między innymi konstytucyjnego prawa równego traktowania obywateli wierzących i niewierzących, które według niektórych ekspertów może zostać naruszone przez artykuł 196 k.k.), poprzez podnoszenie wątpliwości dotyczących obiektu czci religijnej (dyskusja wkracza między innymi w obszar kłopotów ze zdefiniowaniem, czy dany obiekt jest materialnym przedmiotem czy podmiotem czci religijnej osób wierzących). Inna trudność dotyczy przesłanek pozwalających na zdefiniowanie przestępstwa (uczucia religijne przez niektórych prawników oceniane są jako kryterium subiektywne), także definicja sfery publicznej, w której doszło do domniemanego przestępstwa, nie jest wolna od kontrowersji interpretacyjnych, wreszcie eksperckie polemiki rodzi struktura podmiotowej motywacji sprawcy. Rozstrzygnięcie wątpliwości, czy fakt obrażenia uczuć religijnych był występkiem umyślnym ujawniającym się w formie zamiaru bezpośredniego czy ewentualnego, wielokrotnie okazał się decydującym kryterium w wyprowadzeniu werdyktu sądowego.

${ }^{4}$ Członkowie tej organizacji, trzymając się logiki religii publicznej, kwestionowali na przykład zachowania zniesławiające na Węgrzech i w Polsce w latach dziewięćdziesiątych ubiegłego wieku, prowadząc skuteczne działania w obronie swojego dobrego imienia na drodze sądowej (zob. Richardson 1997). 
Wydaje się, że omawiane spory w literaturze pośrednio sygnalizują szerszy problem uwarunkowany faktem zmniejszania się roli religii w strategiach legitymizacji i produkcji wiedzy, pozycji statusowych i relacji władzy w świecie Zachodu, w tym w Polsce. Dlatego wyjście w dyskusji poza wąskie ramy analizy prawnej pozwala na uchwycenia szerszego tła ewolucji kontrowersji dotyczących urażania uczuć religijnych. Prawo regulujące te kontrowersje nie jest neutralne normatywnie, przeciwnie - jest określonym produktem zmiany kulturowej społeczeństw Zachodu i w tym sensie stanowi część określonych metaschematów interpretacyjnych współczesnych systemów politycznych, które krytykę religii zazwyczaj oceniają wyrozumiale. Droga ewolucji dyskursu prawnego powinna być zatem wpisana w schemat interpretacyjny rzeczywistości społecznej zakładający intensyfikację procesów sekularyzacyjnych świata Zachodu, które sprawiają, że miejsce religii systematycznie przesuwane jest w sferę prywatności. Tak między innymi sugerował Christoph Baumgartner (2013, s. 45), który twierdził, że współczesna definicja indywidualnej szkody spowodowanej przez akty godzące w uczucia religijne jest rezultatem zeświecczenia kategorii bluźnierstwa i dlatego na jednostce spoczywa obowiązek udowodnienia, że jej uczucia religijne zostały urażone.

$\mathrm{Na}$ decydującą rolę procesów sekularyzacyjnych w kształtowaniu reakcji społecznych wobec aktów ocenianych jako występek wobec wrażliwości religijnej wskazał ostatnio także Riaz Hassan (2007). Na podstawie danych statystycznych argumentował, że w państwach (o tradycji zarówno chrześcijańskiej, jak i muzułmańskiej), w których procesy sekularyzacji i prywatyzacji religii są zaawansowane, zmniejsza się gotowość wiernych do popierania decyzji o kryminalizowaniu postaw behawioralnych i dyskursywnych ocenianych jako bluźniercze (Hassan 2007).

Z kolei Wendy Smith (2009) przeanalizowała ewolucję kontrowersji dotyczących urażania uczuć religijnych w kontekście „podejrzliwościowych dyskursów", artykułowanych w Europie co najmniej od czasów Oświecenia, które nie tylko kwestionują publiczną rolę religii, ale - co ważniejsze - odrzucają samą formułę racjonalności opartą na przesłankach religijnych. Co więcej, jak stwierdziła Smith, tradycja oświeceniowa - w tym zwłaszcza tradycja krytyczna marksizmu, postmarksizmu i szkoły frankfurckiej, w której religia jest zasadniczo fenomenem fałszywej świadomości - w istotny sposób uwarunkowała infrastrukturę prawa, wiedzy i polityki społeczeństw Zachodu co do relacji sfery świeckiej i religijnej, a tym samym pośrednio wpłynęła na wzmocnienie sceptycyzmu w ocenie normatywnych roszczeń członków wspólnot religijnych, w tym także ochrony uczuć religijnych. Innymi słowy, ta kryptoideologia - wy- 
rastająca między innymi z krytycznej tradycji nowoczesności — zakłada linearny rozwój cywilizacyjny zarządzany racjonalnością progresywizmu historycznego: od bezrozumności i mitologii do racjonalności i bezreligijności. Współczesne tożsamości religijne byłyby rozumiane w tej perspektywie jako fenomeny reliktowe opierające się na zbiorze mitów, którym wprawdzie do pewnego stopnia należy się ochrona, jednak nie za cenę naruszania uprzywilejowanych ideałów świeckich demokracji, między innymi ideału wolności słowa. Zagrożenie ograniczenia wolności słowa W zgodzie $z$ tą logiką - mogłoby ujawnić się podczas próby narzucania świeckiej części społeczeństwa ograniczeń wyrastających z autorytarnych dążeń osób religijnych, których motywacja opiera się na nieweryfikowalnych naukowo archaicznych wierzeniach.

Na niejawność założeń normatywnych świeckiej nowoczesności zwróciła uwagę Saba Mahmood (2009), w dekonstrukcyjnej stylistyce pokazując mechanizmy artykulacyjne nowoczesności wyrastające ze zeświecczonych protestanckich binarnych kategorii, które rozrywają relacje między podmiotem a przedmiotem, substancją a znaczeniem, formą a istotą. Pozwoliło to zredefiniować religię tak, aby uczynić ją spójną z relacjami władzy i strategiami produkcji wiedzy, które - co istotne - zignorowały fakt istnienia obcych postprotestanckiemu uniwersum symbolicznemu „ucieleśnionych praktyk religijnych”, sprawiających, że podmiot (zwłaszcza w katolicyzmie, prawosławiu, islamie i wielu animistycznych kultach) uzyskuje trwałą relacje $z$ sakralnym obiektem. Za sprawą tej redefinicji we współczesnych liberalnych demokracjach kontrowersje dotyczące urażania uczuć religijnych uzyskują inteligibilność w zapośredniczeniu ontologicznych i aksjologicznych założeń charakterystycznych dla logiki „deliberatywności”, „przedstawienia”, „znaczenia” które są nie do pogodzenia ze stanowiskiem wyrastającym z logiki „współistnienia” (cohabitation) "przywiązania” (attachement) i afektywności („affectivitiy”) (Mahmood 2009, s. 842).

Dominacja omawianych niejawnych założeń ideologicznych w obliczu kontrowersji dotyczących urażania uczuć religijnych może prowadzić zarówno do protekcjonalnego traktowania tożsamości religijnych, jak i do postaw nacechowanych pogardą, przemocą symboliczną, co cechuje na przykład dyskursy "orientalistyczne" ${ }^{5}$ w Europie Środkowo-Wschodniej, w których przez odniesienie do uważanych za postępowe wzorów kultury

\footnotetext{
${ }^{5} \mathrm{Na}$ temat dyskursów orientalistycznych zob. m.in. Said 2005; Böröcz 2006; Bakic-Hayden, Hayden 1995.
} 
zachodniej etykietowane są określone segmenty społeczeństwa jako zacofane czy obskuranckie itp. (Buchowski 2006; Zarycki 2015).

\section{KRYTYKA ESENCJALNEJ RACJONALNOŚCI}

Powyższe uwagi korespondują ze znanymi tezami José Casanovy (2005), według którego sekularyzacja jest jedną z fundamentalnych, aczkolwiek niejawnych i nie wyartykułowanych systematycznie ideologii nowoczesności, opartej na założeniu, że wraz z postępem funkcjonalnej dyferencjacji, pluralizmu normatywnego oraz separacji systemów politycznego, naukowego, prawnego i gospodarczego religia będzie tracić zdolność oddziaływania na nowoczesne społeczeństwa szeroko rozumianego Zachodu, zwłaszcza na ich sferę publiczną. Casanova zauważa, że współczesna socjologia rzadko podchodzi do założeń sekularyzacyjnych jako do jednoznacznie adekwatnych narzędzi opisu ewolucji religii we współczesnych społeczeństwach, dane empiryczne przeczą bowiem - wieszczonej między innymi przez Durkheima (1990) i Webera (1964) - nieuchronności sekularyzacji zróżnicowanych funkcjonalnie i normatywnie społeczeństw $^{6}$. Mimo że teoria sekularyzacji jest właściwą perspektywą interpretacji przekształceń wybranych społeczeństw zachodniej Europy (a także niektórych krajów Dalekiego Wschodu, takich jak Japonia), wyprowadzanie z niej uniwersalnej konkluzji, jakoby pełna sekularyzacja miała być nieuchronna, wydaje się empirycznie nieuzasadnione. Nawet jeśli pominiemy dyskusje o transformacji „religii kościelnych” w rozproszone formy „religii niekościelnych”, niezinstytucjonalalizowanych duchowości czy niewidzialnych religii (zob. m.in. Luckmann 1996) i skupimy się na wspólnotach tradycyjnych, to jesteśmy świadkami wielu zjawisk, które tej teorii przeczą. Jest to $z$ jednej strony nieprzerwane ożywienie religijne wybranych społeczeństw świata islamu (np. wzrost integryzmu islamskiego na Bliskim Wschodzie, ekspansja w Południowo-Wschodniej Azji) czy chrześcijaństwa afrykańskiego, azjatyckiego i latynoskiego, a z drugiej strony $\mathrm{w}$ wybranych wysoko rozwiniętych państwach kapitalistycznych zauważalne są zjawiska świadczące o niemalejącym znaczeniu religii dla ich społeczeństw (np. fenomen szeroko rozumianego ruchu New Born Christians w Stanach Zjednoczonych czy rosnących wpływów chrześcijan w życiu pu-

\footnotetext{
${ }^{6}$ Innym ważnym badaczem religii, który w latach sześćdziesiątych XX wieku zakładał nieuchronność procesów sekularyzacyjnych, był Peter Berger (1979). Po latach odstąpił on od rozumienia sekularyzacji jako zjawiska nieuchronnie związanego z modernizacją (Berger 1999).
} 
blicznym Korei Południowej). Także wybrane kraje Europy Wschodniej po 1989 — kiedy to zakładano nastąpienie konwergencji tej części Europy do standardów sekularyzacyjnych Europy Zachodniej — raczej nie potwierdzają tych oczekiwań. Na przykład mimo niewątpliwej obecności w Polsce tendencji sekularyzacyjnych, zwłaszcza w wybranych regionach (Polska Północno-Zachodnia) i dużych ośrodkach miejskich, religijność społeczeństwa polskiego w ostatnich dekadach jest relatywnie stabilna (mierzona na przykład częstotliwością praktyk religijnych czy odsetkiem powołań kapłańskich) (Zdaniewicz, Zembrzuski 2000; Hall 2012).

Sekularyzacja traci swą nieuchronność także w świetle późnonowoczesnej krytyki esencjalnej racjonalności ${ }^{7}$, która zakłada linearną czy dialektyczną ewolucję historii (jak w ortodoksyjnej wykładni marksizmu, a także w klasycznej teorii sekularyzyacyjnej) w kierunku określonej apriorycznej racjonalności, na przykład triumfu sekularności nad religijnością. Chociaż z perspektywy funkcjonalistycznej współczesne subsystemy religijne zajmują pozycję podporządkowaną (np. wobec subsystemu prawnego czy gospodarczego), zaproponowanej perspektywie antyesencjalistycznej ${ }^{8}$, dla której jednym z podstawowych znaków późnej nowoczesności jest brak prawomocnego kryterium rozstrzygającego kwestię uniwersalnie obowiązujących norm racjonalności ${ }^{9}$ (Marchart 2007, s. 55), nie sposób wykazać uprzywilejowania pozycji subsystemów świeckich wobec subsystemów religijnych. W dobie tak rozumianego kryzysu esencjalnego uniwersalizmu (pojmowanego jako samouprawomacniająca się racjonalność obowiązująca w tym samym stopniu w różnych polach społecznych) przywołana krytyka sugeruje potrzebę zastosowania analizy partykularnych strategii artykulacyjnych tworzących efekt naturalizacji faktów, które następnie mogą

${ }^{7}$ Esencja zazwyczaj jest definiowana jako właściwość obiektu, stała, niezmienna i niezależna od relacji, czyli substancja, która nie podlega przeobrażeniom w zbiorze różnic pola języka.

${ }^{8}$ Filozofia, teoria społeczna, antropologia i psychologia późnej nowoczesności przyniosły wiele kluczowych przewartościowań ideałów założycielskich nowoczesności, w tym samej zasady racjonalności (Derrida 1999; Foucault 1977), kategorii uniwersalności (Laclau, Mouffe 2007) czy świadomej podmiotowości (Freud 1998, 2000; Lacan 1977).

${ }^{9}$ François Lyotard (1997, s. 111) pisze o kryzysie wiarygodności wielkich narracji spekulatywnych i emancypacyjnych. Richard Rorty $(1996,1999)$ podkreśla, że przygodność jest podstawową kategorię przenikającą późną nowoczesność. Oznacza to zanik kategorii absolutnej prawdy i absolutnie obowiązujących norm aksjologicznych. Nierozstrzyglność to — według Rorty'ego - niezdolność do ustalenia absolutnych kryteriów wyboru: wszystkie prawdy są relatywne, w tej mierze, w jakiej nie sposób wskazać absolutnego kryterium, które zajmowałoby „nieporuszone” i „zewnętrzne” miejsce, pozwalające na dokonanie rozstrzygnięcia o „prawomocności” którejś z prawd. 
być oceniane jako „urażenie wrażliwości religijnej” albo „brak urażenia wrażliwości religijnej”. Wobec niemożliwości ustalenia absolutnego kryterium rozstrzygającego obiektywnie, co stanowi przykład urażenia uczuć religijnych, należałoby raczej wykazać, że specyficzne wspólnoty polityczne, a także nieformalne grupy nacisku kulturowego, decydują pragmatycznie, jakim symbolom w danym momencie historycznym należy się szacunek i ochrona. Doświadczenie europejskie sugeruje, że narody korzystają ze spluralizowanych normatywnie schematów interpretacyjnych konstruowanych przez różne doświadczenia historyczne, ocenę miejsca Kościołów w życiu publicznym czy stopień sekularyzacji społeczeństwa. Na przykład w krajach skandynawskich, gdzie liczba osób religijnych jest znikoma, a stopień oddziaływania religii na życie publiczne nieznaczny, postulowanie, aby karać dziennikarzy za publikację karykatur Mahometa, musiało rzecz jasna brzmieć nieprzekonująco. $Z$ kolei w Polsce zasoby religijne odgrywają zauważalną rolę w legitymizacji zbiorowych działań społecznych, które niekiedy rodzą antagonistyczne skutki, zwłaszcza w przestrzeni politycznej. Polska bowiem, nawet na tle postkomunistycznego regionu Europy Środkowej jest krajem dotkniętym intensywnym sporem politycznym, który z różnym natężeniem ciągnie się od przełomu 1989 roku i zasadniczo jest wyznaczony kategoriami kulturowymi i symbolicznymi (Brubaker 1996; Jasiewicz 2009; Zarycki, Smoczyński, Warczok 2017). Obok różnych innych kwestii spór ów dotyka także zagadnień religijnych i etycznych (miejsca Kościoła katolickiego w życiu publicznym, kryminalizacji aborcji itp.). Jeśli weźmie się pod uwagę tę osobliwość, że Polacy rzadziej niż większość społeczeństw Zachodu organizują napięcia w debacie publicznej wokół twardych parametrów społeczno-ekonomicznych (polityki podatkowej, podziałów klasowych), lecz czynią to wokół kategorii symbolicznych, to w oczywisty sposób kwestia obrazy uczuć religijnych może odgrywać istotną rolę $\mathrm{w}$ politycznych strategiach artykulacyjnych.

\section{PERSPEKTYWA AFEKTYWNEJ LOGIKI PODMIOTU}

Wydaje się, że największy rezonans w literaturze przedmiotu wywołała publikacja Saby Mahmood (2009). Intrygującym wątkiem jej analizy jedynie zdawkowo podjętym w dyskusji akademickiej — była próba zwrócenia uwagi na fakt, że symbole religijne przez pewne jednostki, ale także przez określone segmenty społeczeństw, mogą być odbierane nie tylko jako abstrakcyjne znaki (znaczące) reprezentujące określoną substancję sakralną (znaczone), ale odwrotnie - jako znaki nierozdzielnie związane $z$ tą sakralną substancją (przypominając $\mathrm{W}$ tym podejście społeczności 
animistycznych do obiektów sakralnych). Według Mahmood zatem religijność nie sprowadza się do stanu wierzeń (rozumianych jako fenomen psychologiczny), ale jest habitusem urzeczywistnionym w ucieleśnionych praktykach wyrażonych między innymi żywą relacją do symboli czy naśladowaniem cnót świętych osób lub założycieli religii (Mahomet), co „materialnie” formuje tożsamości jednostek. Należy zauważyć, że taka identyfikacja wiernego $z$ symbolem, wyrażana na przykład $\mathrm{w}$ naśladowaniu osoby Chrystusa ma także długą tradycję w chrześcijaństwie: od mistycznego zjednoczenia wiernego $z$ Chrystusem do potocznych praktyk pobożnościowych.

Poświęcono tej ścieżce religijności indywidualnej i zbiorowej wiele publikacji apologetycznych, których jednym z najważniejszych przykładów jest O naśladowaniu Chrystusa Tomasza à Kempis. Dlatego obrażenie uczuć religijnych - podążając za wywodem Mahmood (2009) — nie dotyka abstrakcyjnej sfery wierzeń, ale samego rdzenia tożsamości osoby religijnej. W wyjaśnieniu takiej logiki religijności autorka sięgnęła między innymi do koncepcji W.J.T. Mitchella, który twierdzi, że nie wszystkie semiotyczne formy opierają się na logice znaczenia, komunikacji i reprezentacji, a tym samym akty godzące $\mathrm{w}$ określone symbole religijne nie mają charakteru li tylko abstrakcyjnego. Ten aspekt tekstu, który w wyjaśnieniu „straty moralnej" jednostki na skutek doświadczenia urażenia uczuć religijnych sięga po kategorię ucieleśnionej funkcji symbolu religijnego dla osoby religijnej, wymaga pogłębienia. Na potrzebę poprawienia analitycznej precyzji tego aspektu argumentacji Mahmood zwrócił uwagę między innymi Andrew March (2012) twierdząc, że uzasadnienie kategorii „straty moralnej” i afektywnej kohabitacji miejscami jest niejasne i zdawkowe.

Wydaje się, że rozszerzenie analizy roli symbolu religijnego przez wiernego rozumianego jako podmiot afektu może uzyskać większą analityczną klarowność w perspektywie socjologii durkheimowskiej, według której symbol pełni funkcję centralnego punktu odniesienia dla wspólnoty religijnej — jest źródłem jej moralnego istnienia. Według tej argumentacji symbol - który we wspólnotach religijnych zazwyczaj jest uosabiany przez określony przedmiot (jak w analizowanych przez Durkheima wspólnotach totemicznych), ale symbolem może być też sama nazwa wyraża ideał pełni moralnej łączącej członków wspólnoty i to ten ideał jest właściwym przedmiotem kultu (Durkheim 1990, s. 181-182). Wszelka postać życia społecznego może istnieć tylko dzięki zapośredniczeniu przez rozległy system symboli wyrażających świadomość wspólnotową, która przekracza świadomość jednostkową: wyobrażenie zbiorowe może zyskać samoświadomość, gdy zwiąże się z określonym obiektem (nazwą 
lub przedmiotem materialnym) (Durkheim 1990, s. 228), gdyż: „ani kreacja, ani rekreacja społeczeństwa nie jest możliwa bez jednoczesnej kreacji tego, co idealne" (Durkheim 1990, s. 403). To, co idealne, to jest właśnie ideał określonej wspólnoty moralnej, który nie jest określonym faktem empirycznym, ale stanowi określony ideał pełni życia moralnego, oczywiście niemożliwy do urzeczywistnienia ${ }^{10}$. Ów „brak pełni”, zdaniem Durkheima, jest źródłem kultu sakralnego zapośredniczonego przez symbole, które są jednocześnie punktem oparcia wspólnoty moralnej ${ }^{11}$. Innymi słowy, obiekty religijne są jedynie materialnym wyrazem sił moralnych i dopiero w roli reprezentanta „czegoś, co je przekracza” stają się przedmiotem sakralizacji. W tak zdefiniowanej perspektywie, w której sakralne obiekty dostarczają wspólnocie moralnego punktu oparcia, kategoria „obrażenia uczuć religijnych" nie dotyczy abstrakcyjnych „treści życia psychicznego”, a protesty osób religijnych mogą być wyrazem obrony „wspólnoty moralnej" uosabianej przez dany obiekt czy nazwę.

Religijny symbol uaktywniany w rytuałach społecznych jest miejscem obsadzenia uniwersalnych „sił moralnych wspólnoty”, a rytualny mechanizm rekonstrukcji „całości” w obrębie „części” odsyła do źródeł tego, co sakralne i mityczne. Tym samym symbol czczony w praktykach pobożnościowych wspólnoty staje się gwarantem jej bezpieczeństwa ontologicznego: „[Z] punktu widzenia myślenia religijnego część to to samo, co całość; część ma tę samą moc i skuteczność. Fragment relikwii i relikwia w całości mają jednakie właściwości, a najmniejsza kropla krwi i wszelka krew zawierają ten sam aktywny pierwiastek" (Durkheim 1990, s. 221). Co jednak czyni ów partykularny obiekt czymś sakralnym? Durkheim twierdzi, że „siła sakralna”, która jest „uczuciem wzbudzonym w członkach zbiorowości", to to uczucie przemienia dany obiekt kultu w figurę

10 „Społeczeństwo idealne nie istnieje poza społeczeństwem rzeczywistym, jest jego częścią. To wcale nie jest sprawa wyboru między dwoma odpychającymi się biegunami, jedna zależność jest warunkiem drugiej. Społeczeństwo bowiem to nie po prostu ogół składających się na nie jednostek, ziemia na której osiadły, wykorzystywane przez nie rzeczy, spełniane czynności; to przede wszystkim jego własna idea samego siebie. [...] Tak więc zdolność idealizacji nie ma w sobie tajemniczego zarówno w przypadku jednostki, jak grupy. To nie żaden luksus, bez którego człowiek mógłby sie obejść, lecz warunek jego istnienia" (Durkheim 1990, s. 404). „Idea samego siebie” to ostatecznie, zdaniem Durkheima (1990, s. 224-225) efekt identyfikacji z pewnym symbolem.

11 „Sacrum to z definicji coś, co uzupełnia rzeczywistość. Otóż to, co idealne, definiuje się tak samo.[...] Realny świat codzienności człowieka przesłania światem innym, który $\mathrm{w}$ pewnym sensie istnieje tylko w jego myśli, ale któremu przyznaje większy w porównaniu z tamtym autorytet. Jest to więc z tych dwóch powodów świat idealny" (Durkheim 1990, s. 403). 
reprezentującą całość. A zatem „charakter sakralny rzeczy - pisze Durkheim (1990, s. 221) — nie wynika z jej wewnętrznych właściwości, jest w niej czymś dodatkowym. Sfera rzeczy sakralnych to nie szczególna postać rzeczywistości empirycznej, to jej dodatkowa warstwa”. Dokładnie taka jest funkcja symboli religijnych, które przez afektywny dodatek osób religijnych przeobraża ich partykularną empiryczną postać w reprezentację wspólnoty moralnej ${ }^{12}$.

Ponadto także perspektywa afektywna tłumaczy, dlaczego na przykład karykaturalnie zniekształcony wizerunek Mahometa czy zdeformowany krzyż z instalacji Nieznalskiej zwykle nie są traktowane przez wybranych muzułmanów i katolików ze stoicką pobłażliwością (chodzi głównie o wiernych reprezentujących tak zwaną "religijność wewnętrzną", używając kategorii Allporta i Rossa (1967), albo innymi słowy zdolnych do intensywniejszego afektywnego związku z symbolami religijnymi). W perspektywie afektywnej, gdy symbole zawierają ów „nadmiar”, nie mamy do czynienia z obiektami neutralnymi normatywnie. Jak w perspektywie postrukturalistycznej zauważali Slavoj Žižek (2001) czy Yannis Stavrakakis (1999) i Terrence Deacon (Deacon, Cashman 2009) w perspektywie kognitywistyki ewolucyjnej, logika „afektywnej ekonomii” sprawia, że postrzeganie jednostki w określonym stanie pobudzenia emocjonalnego umożliwia przekształcania postaci rzeczywistości materialnej i symbolicznej.

W związku z tym, że dynamika afektywności tworzy swoisty efekt anamorfozy i nie jest zarządzana przez zespół „obiektywnych” kryteriów, które pozwalają na przykład orzec, jaki stopień znieważenia czczonego symbolu może zostać oceniony jako bluźnierczy/obraźliwy, jednostka albo wspólnota spontanicznie decyduje/decydują czy określona zniekształcona ilustracja obiektu sakralnego ją/ich obraża. Mówiąc obrazowo, uświadomienie sobie faktu urażenia uczuć religijnych przez członków danej wspólnoty nie wymaga, aby uprzednio przeprowadziki oni konsultacje $z$ biegłym w dziedzinie historii sztuki teologii czy ekspertem jakiejkolwiek wykładni racjonalnej reakcji wobec aktu ocenianego przez wiernych jako znieważający ich uczucia religijne. Te treści odbierane są przez jednostki spontanicznie $\mathrm{w}$ porządku afektywnym i jednocześnie są porównywane $z$ dostępną rutynową wiedzą na temat tradycyjnego wizerunku symboli religijnych; w wyniku kontrastu (np. karykatura symbolu versus tradycyjny wizerunek symbolu) u wśród wybranych członków grupy pojawia się dysonans poznawczy.

12 „Sakralność bowiem to w rzeczywistości szczególny rodzaj emocji” (Durkheim 1990). 
Co ważne, ta arbitralność wyrastająca $z$ afektywnej logiki osoby religijnej jest źródłem nieuchronnych ambiwalencji o poważnych konsekwencjach społecznych i politycznych. Mianowicie integracji wspólnot religijnych za pośrednictwem symboli często towarzyszy obawa ich członków przed różnymi kategoriami Innych, którzy realnie lub fantazmatycznie kwestionują zbiorowe siły moralne wspólnoty ${ }^{13}$. Ta nierozdzielność „Nas” i „Innych” historycznie towarzyszyła procesowi konstytuowania różnych tożsamości religijnych, dlatego też — jak zauważył między innymi James Beckford (2006) - wspólnoty religijne mogą być elementem budowania ładu społecznego, ale też mogą wzniecać antagonizmy, niepokoje i przemoc. Kontrowersje dotyczące urażonej dumy, wrażliwości czy doktryny religijnej w określonych sytuacjach prowadziły do aktów fundamentalizmu, przemocy religijnej i panik moralnych, co niekiedy drastycznie naruszało spójność społeczną. Historia uczy na przykład, że jednym ze źródeł fanatyzmu religijnego jest długotrwałe doświadczenie wykluczenia i upokorzenia członków wspólnot religijnych, jak chociażby w świeckim reżimie Rezy Pahlaviego, ostatecznie obalonym przez irańską rewolucję islamistyczną. Te doświadczenia niekoniecznie odnoszą się tylko do napięcia wywołanego przymusową polityką sekularyzacji, ideologie religijne często bowiem pokrywają się z resentymentami nacjonalistycznymi i nie dotyczą tylko kultury islamu: systematyczne upokarzanie katolików w Irlandii Północnej wywołało ciągnący się przez dekady terror katolicko-nacjonalistycznej IRA, zakończony stosunkowo niedawno tzw. porozumieniem wielkopiątkowym.

\section{KONKLUZJA}

W świetle zaproponowanej argumentacji durkheimowskiej symbole religijne są rozumiane jako wyraz spoistości wspólnoty moralnej, wybrane akty godzące $\mathrm{w}$ symbole przez wybrane grupy religijne nie są zatem traktowane jako trywialne gesty, ale jako akty wymierzone $w$ zasadę ontologicznego poczucia bezpieczeństwa ich członków, co w określonych sytuacjach może pogłębiać antagonizm społeczny. Racjonalni uczestnicy debaty publicznej zazwyczaj zgadzają się, że unikanie działań, które mogą wzniecać ekstremizm religijny, jest w szeroko rozumianym interesie społecznym - temu służą między innymi apele władz europejskich

${ }^{13} \mathrm{Na}$ integrację grupy w procesie sublimacyjnym — zwróciła ostatnio uwagę m.in. Mouffe, powołując się na koncepcję ewolucji kultury według Freuda. Ten proces jest możliwy przy jednoczesnym identyfikowaniu „Nas” i „Innych” (Mouffe 2005, s. 25-26; Freud 1998, s. 206) 
o unikanie stosowania retoryki odpowiedzialności zbiorowej w przypadku terroru motywowanego ekstremizmem islamskim. Ostatecznie nie jest czymś zaskakującym, że kultura polityczna społeczeństw europejskich, doświadczonych wojnami religijnymi, świadomych ambiwalencji zasobów religijnych, zaleca unikanie atakowania obiektów i tożsamości religijnych.

Na niebezpieczeństwo „rozszczelnienia ładu społecznego” przez konflikt religijny i $\mathrm{w}$ związku $\mathrm{z}$ tym na potrzebę chronienia uczuć religijnych nawet za cenę ograniczenia absolutnej zasady wolności słowa - jak stwierdził znacząco Jones (1980) - zwracali i zwracają uwagę nie tylko konserwatywni filozofowie polityczni, ale także ideologowie liberalizmu, począwszy od Milla, na libertarianie Nozicku kończąc. Specyficzne ryzyko rozszczelnienia ładu społecznego w wyniku kontrowersji dotyczących urażania uczuć religijnych ujawnia się także omawiana już krytyka esencjalistycznego racjonalizmu. W takim kontekście oczywiście jest utrudnione wyprowadzenie deliberatywnego rozwiązania sporu między rzecznikami ochrony wolności religijnej i wolności słowa, które zadawalałoby obie strony.

W tym miejscu należy przywołać Chantal Mouffe (2005, 2008), która zauważyła, że współczesne pluralistyczne systemy społeczne zorganizowane są na przecięciu nierówności relacji władzy. Innymi słowy - jeśli jakaś tożsamość uzyskuje przewagę, to zawsze za cenę wykluczenia innej. Zdaniem Mouffe idealistycznym przesądem jest wiara w radykalny pluralizu i heterogeniczność wszystkich postulatów społecznych, które mogłyby nieantagonistycznie koegzystować, na przykład w wyniku stałego procesu społecznej racjonalnej debaty. Dlatego w zgodzie $z$ tą linią argumentacyjną rozstrzygnięcie sporu („obraził uczucia religijne” czy „nie obraził uczuć religijnych) oznaczałoby wykluczenie któregoś z antagonistycznych stanowisk i uprzywilejowanie jednego z nich. Mouffe twierdzi wszelako, że właśnie dlatego, iż konflikt społeczny jest niemożliwy do uniknięcia, zadaniem polityki jest redukowanie intensywnego antagonizmu (konfliktu wrogów delegitymizujących swoje tożsamości) i przesuwanie konfliktu społecznego w stronę ,agonicznego” sporu rywali nie naruszających pewnych wspólnych granic symbolicznych, po przekroczeniu których rywal staje się wrogiem, a polityka antagonistyczna rozbija wspólnotę, w wyniku czego tracą wszyscy. Akt znieważenia osób o odmiennej tożsamości może podważyć wspólną symboliczną podstawę uczestników demokratycznej debaty, może wzniecać prawicowy populizm i fanatyzm religijny, a tym samym może szkodzić stabilności demokracji liberalnej. Jednocześnie należy pamiętać o szczególnej funkcji wolności obywatelskich w świecie Zachodu, które niekiedy mogą i są realnie atakowane przez przedstawicieli in- 
tegryzmu religijnego pod pretekstem ochrony uczuć religijnych. Podejście zaproponowane przez Chantal Mouffe sugeruje, że rozstrzygnięcie napięcia wymaga każdorazowej analizy specyficznego kontekstu relacji władzy, co pozwoli na ustalenie, czy uprzywilejowanie określonej strony konfliktu wobec faktu generowania frustracji drugiej strony jest zgodne $z$ aktualnie dominującym konsensualnym interesem społecznym.

\section{BIBLIOGRAFIA}

Allport Gordon W., Ross Michael J., 1967, Personal Religious Orientation and Prejudice, „Journal of Personality and Social Psychology", t. 5(4), s. 432-443.

Bakic-Hayden Milica, Hayden Robert M., 1995, Nesting Orientalism: The Case of Former Yugoslavia, „Slavic Review”, t. 54(4), s. 917-931.

Baumgartner Christoph, 2013, Blasphemy as Violence: Trying to Understand the Kind of Injury that Can Be Inflicted by Acts and Artefacts That Are Construed As Blasphemy, „Journal of Religion in Europe", t. 6(1), s. 35-63.

Beckford James, 2006, Teoria społeczna a religia, tłum. Magdalena Kunz, Tomasz Kunz, Nomos. Kraków.

Berger Peter, 1979, The Heretical Imperative: Contemporary Possibilities of Religious Affirmation, Doubleday, New York.

Berger Peter (red.), 1999, The Desecularization of the World. Resurgent Religion and World Politics, Eerdmans Publishing, Washington, D.C.

Böröcz József, 2006, Goodness Is Elsewhere: The Rule of European Difference, „Comparative Studies in Society and History", t. 48(1), s. 110-138.

Brubaker Rogers, 1996, Nationalism Reframed: Nationhood and the National Question in the New Europe, Cambridge University Press, Cambridge.

Buchowski, Michał, 2006, The Specter of Orientalism in Europe: From Exotic Other to Stigmatized Brother, „Anthropological Quarterly”, t. 79(3), s. 463-482.

Carens Joseph, 2006, Free Speech and Democratic Norms in the Danish Cartoon Controversy, „International Migration", t. 44(5), s. 33-42.

Casanova José, 2005 Religie publiczne w nowoczesnym świecie, tłum. Tomasz Kunz, Nomos, Kraków.

Cohen Stanley, 1972, Folk Devils and Moral Panics: The Creation of the Mods and Rockers, Martin Robertson, Oxford.

Deacon Terrence, Cashman Tyrone, 2009, The Role of Symbolic Capacity in the Origins of Religion, „Journal for the Study of Religion, Nature and Culture”, t. 3(4), s. 1-28.

Derrida Jacques, 1999, O gramatologii, tłum. Bogdan Banasiak, Wydawnictwo KR, Warszawa.

Durkheim Émile, 1973, Moral Education, Free Press, New York.

Durkheim Émile, 1990, Elementarne formy życia religijnego, tłum. Anna Zadrożyńska, Wydawnictwo Naukowe PWN, Warszawa.

Dziwisz Stanisław, 2017, Odpowiedzialność karna artysty za przestępstwo obrazy uczuć religijnych, „Roczniki Nauk Prawnych”, t. 27(1), s. 7-22.

Foucault Michel, 1977, Archeologia wiedzy, tłum. Andrzej Siemek, Państwowy Instytut Wydawniczy, Warszawa. 
Foucault Michel, 1998, Nadzorować i karać. Narodziny więzienia, tłum. Tadeusz Komendant, Fundacja Aletheia, Warszawa.

Freud Sigmund, 1998, Kultura jako źródło cierpień, w: Sigmund Freud. Pisma społeczne, tłum. różni, Wydawnictwo KR, Warszawa.

Freud Sigmund, 2000, Poza zasada przyjemności, tłum. Jerzy Prokopiuk, Wydawnictwo Naukowe PWN, Warszawa.

Fuchs Katarzyna, Kamiński Ireneusz C., 2009, Spór wokót publikacji karykatur Mahometa, „Problemy Współczesnego Prawa Międzynarodowego, Europejskiego i Porównawczego", t. 7, numer specjalny „Ochrona praw człowieka”.

Goode Erich, Ben-Yehuda Nachman, 1994, Moral Panics: The Social Construction of Deviance, Oxford University Press, New York.

Gryz Krzysztof, 2013, Sprzeciw sumienia w kulturze, „Teologia i Moralność”, nr 2, s. 101-115 .

Hall Dorota, 2012, Questioning Secularization? Church and Religion in Poland, w: Detlef Pollack, Olaf Muller, Gert Pickel (red.), The Social Sigificance of Religion in Enlargded Europe, Secularization, Individualization and Pluralization, Ashgate, Farnham.

Hassan Riaz, 2007, Expressions of Religiosity and Blasphemy in Modern Societies, „Asian Journal of Social Science", t. 35(1), s. 111-125.

Hunt Alan, 1999, Governing Morals: A Social History of Moral Regulation, Cambridge University Press, Cambridge.

Jasiewicz Krzysztof, 2009, “The Past Is Never Dead”. Identity, Class, and Voting Behavior in Contemporary Poland, „East European Politics and Societies”, t. 23(4), s. 491-508.

Jones Peter, 1980, Blasphemy, Offensiveness and Law, „British Journal of Political Science”, t. 10(2), s. 129-148.

Kłaczyńska Natalia, 2014, Komentarz do art. 196 k.k., w: Kodeks karny. Część szczególna, Jacek Giezek (oprac.), Wolters Kluwer, Warszawa, s. 497-514.

Lacan Jacques, 1977, The Seminar. Book XI. The Four Fundamental Concepts of Psycho-Analysis, 1964, W.W. Norton, London.

Laclau Ernesto, Mouffe Chantal, 2007, Hegemonia i socjalistyczna strategia: przyczynek do projektu radykalnej polityki demokratycznej, tłum. Sławomir Królak, Wydawnictwo Naukowe Dolnośląskiej Szkoły Wyższej Edukacji TWP, Wrocław.

Levy Leonard W., 1993, Blasphemy: Verbal Offense against the Sacred from Moses to Salman Rushdie, Alfred Knopf, New York.

Luckmann Thomas, 1996, Niewidzialna religia. Problem religii we wspótczesnym społeczeństwie, tłum. Lucjan Bluszcz, Nomos, Kraków.

Lyotard Jean-François, 1997, Kondycja ponowoczesna. Raport o stanie wiedzy, tłum. Małgorzata Kowalska, Jacek Migasiński, Fundacja Aletheia, Warszawa.

Mahmood Saba, 2009, Religious Reason and Secular Affect: An Incommensurable Divide?, „Critical Inquiry”, t. 35(4), s. 836-862.

March Andrew, 2012, Speech and the Sacred: Does the Defense of Free Speech Rest on a Mistake about Religion?, „Political Theory”, t. 40(3), s. 319-346.

Marchart Oliver, 2007, Post-foundational Political Thought: Political Difference in Nancy, Lefort, Badiou and Laclau, Edinburgh University Press, Edinburgh.

Mouffe Chantal, 2005, Paradoks demokracji, tłum. różni, Wydawnictwo Naukowe Dolnośląskiej Szkoły Wyższej Edukacji TWP, Wrocław. 
Mouffe Chantal, 2008, Polityczność. Przewodnik „Krytyki Politycznej”, tłum. Joanna Erbel, Wydawnictwo Krytyki Politycznej, Warszawa.

Parsons Talcott, 1954, Essays in Sociological Theory, Free Press, New York.

Richardson James T., 1997, New Religions and Religious Freedom in Eastern and Central Europe: A Sociological Analysis, w: Irena Borowik, Grzegorz Babiński (red.), New Religious Phenomena in Central and Eastern Europe, Nomos, Krakow.

Rorty Richard, 1996, Przygodność, ironia i solidarność, tłum. Wacław Jan Popowski, Spacja, Warszawa.

Rorty Richard, 1999, Obiektywność, relatywizm i prawda, tłum. Janusz Margański, Fundacja Aletheia, Warszawa.

Said Edward W., 2005 [1978], Orientalizm, tłum. Monika Wyrwas-Wiśniewska, Zysk i S-ka, Poznań.

Smith Wendy, 2009, Introduction. Is Critique Secular? Blasphemy, Injury, and Free Speech, „The Townsend Papers in the Humanities", nr 2, s. 7-20.

Stavrakakis Yannis, 1999, Lacan and Political, Routledge, London-New York.

Tokarska-Bakir Joanna, Zawadzka Anna, 2015, Blasfemia, „Studia Litteraria et Historica”, nr 3-4.

Tomkiewicz Małgorzata, 2012, Obraza uczuć religijnych katolika w Polsce. Czy to możliwe?, „Seminare", t. 32, s. 123-135.

Weber Max, 1964, Religius Rejections of the World and Their Directions, w: Hans H. Gerth, C. Wright Mills (red), From Max Weber, Oxford University Press, New York.

Zarycki Tomasz, 2015, Ideologies of Eastness in Central and Eastern Europe, Routledge, London.

Zarycki Tomasz, Smoczynski Rafał, Warczok, Tomasz, 2017, The Roots of Polish Culture-Centered Politics: Toward a Non-Purely Cultural Model of Cultural Domination in Central and Eastern Europe, „East European Politics and Societies and Cultures”, t. 20(10), s. 1-22.

Zdaniewicz Witold, Zembrzuski Tadeusz, 2000, Kościót i religijność Polaków 1945-1999, Instytut Statystyki Kościoła Katolickiego SAC, Warszawa.

Žižek, Slavoj, 2001, Wzniosty obiekt ideologii, tłum. Joanna Bator, Paweł Dybel, Wydawnictwo Uniwersytetu Wrocławskiego, Wrocław.

Żukowska Małgorzata, 2016, Kryminalizacja obrazy uczuć religijnych $w$ polskim prawie karnym, „Zeszyty Prawnicze”, t. 16(1), s. 201-217.

\title{
SECULARIZATION, AFFECTIVENESS, AND ANTAGONISM- SELECTED ISSUES IN ANALYZING THE CONTROVERSY OVER OFFENDING RELIGIOUS FEELINGS
}

\author{
Rafał Smoczyński \\ (Institute of Philosophy and Sociology of the Polish Academy of Sciences)
}

\section{Abstract}

In analyzing selected aspects of the debate over offending religious feelings, the author discusses Saby Mahmood's argument that religiousness in public discourses of the Western world is basically perceived as a speculative phenomenon concerning the sphere of abstract beliefs. It is assumed therefore that the harm 
that can be produced by the publication of a blasphemous illustration is lesser and less palpable than in the case of hate speech directed toward a race or sexual orientation. The author's analysis, which is undertaken from a Durkheim perspective, shows that, for example, the caricaturized presentation of a religious symbol constitutes not so much an act of undermining the abstract image as-in the affective perspective of the religious-an act violating the sense of ontological security of a given moral community which that symbol represents. At the same time, the Durkheim perspective facilitates an understanding of why religious symbolic resources can be ambivalently used in processes of legitimating social actions, beginning with constructive forms of civil public religions to extreme fundamentalist movements making use of violence and the discourses of political extremism.

Key words / słowa kluczowe

offending religious feelings / obrażanie uczuć religijnych, blasphemy / bluźnierstwo, secularization / sekularyzacja, affectiveness / afektywność, social antagonism / antagonizm społeczny 